DOI 10.18551/rjoas.2019-09.16

\title{
THE INFLUENCE OF TRANSFORMATIONAL LEADERSHIP STYLE, WORK ENVIRONMENT, AND COMPENSATION ON TEACHER SATISFACTION IN SMKN 2 KENDARI
}

\author{
Febriansyah Ahmad, Student \\ Master's Program in Management Science, University of Halu Oleo, Kendari, Indonesia
}

Hajar Ibnu, Awasinombu Aidin Hudani, Lecturers

Faculty of Economics and Business, University of Halu Oleo, Kendari, Indonesia

*E-mail: ryanbojes20@gmail.com

\begin{abstract}
To bring together the goals of the individual and the organization, it is necessary to endeavor a variety of ways to produce an added value by motivating the teacher to be more active and enthusiastic in working. Hence, teacher satisfaction will increase and feel comfortable with the work assigned to him. Teacher satisfaction can also improve the quality of education in schools. This study was explanatory research with survey methods to find causal relationships between variables through hypothesis testing. Transformational Leadership Style, Work Environment, and Compensation simultaneously had a positive and significant effect on Teacher Satisfaction of SMKN 2 Kendari. Transformational Leadership Style partially had a positive and significant effect on teacher satisfaction of SMKN 2 Kendari. Work environment partially had a positive and significant effect on teacher satisfaction of SMKN 2 Kendari. Compensation partially had a positive and significant effect on teacher satisfaction of SMKN 2 Kendari. As additional information for schools in Kendari, particularly SMKN 2 Kendari in evaluating transformational leadership styles, work environments, and compensation that affect teacher satisfaction.
\end{abstract}

\section{KEY WORDS}

Transformational leadership style, work environment, compensation, teacher satisfaction.

People play an important role in organizational activities, so their views or needs is important to know. If it can be detected, people as a resource can be a key and reliable factor as the basis for a healthy and happy human relationship. Therefore, people can work enthusiastically and are capable of increasing their productivity optimally. To bring together the goals of the individual and the organization, it should endeavor a variety of ways to produce an added value from these human resources by motivating the teacher to be more active and enthusiastic. For that matter, teacher satisfaction will increase and feel comfortable with the work assigned to him. Also, it will improve the quality of education in schools. Triffin (as quoted in As'ad, 1998) suggested that job satisfaction is related to the attitude of employees towards the job itself. Robbins (1996) stated that job satisfaction is the general attitude of an individual towards his/her job. Someone with a high level of job satisfaction has a positive attitude towards his/her job. Transformational leadership is a leadership model for a leader who tends to motivate subordinates to work better and focus on behavior to help transformation between individuals and organizations. A good work environment will influence the teacher's physical or mental condition in doing his/her work. According to Ahyari (2005), work environment factors are a place where workers are employed and prepared by the management. The work environment is one of the determinants factors of teacher satisfaction to do their jobs. Several matters meant in this case are facilities, school organizational structure, security, and leadership. The problem appeared in SMKN 2 vocational high school in Kendari is the dissatisfaction of the teacher's performance caused by the lack of leadership supervision, both technical supervision and support from superiors to the rules set there. Also, the work environment and rewards that 
support teachers in performing their task. Based on the background described above, the researchers are interested in investigating "The influence of transformational leadership style, work environment, and compensation on teacher satisfaction of SMKN 2 Kendari. The objectives of this research were as follows: (1) Determining and analyzing the effect of transformational leadership, work environment, and compensation on teacher satisfaction of SMKN 2 Kendari; (2) Finding out and analyzing the influence of transformational leadership style on teacher satisfaction of SMKN 2 Kendari. (3) Finding out and analyzing the influence of the work environment on teacher satisfaction of SMKN 2 Kendari. (4) Finding out and analyzing the effect of compensation on teacher satisfaction of SMKN 2 Kendari.

\section{LITERATURE REVIEW}

Human resource challenges faced by managers and organizations: economic and technological changes; issues of labor force availability and quality; and demographics and organizational rearrangement (Mathis and Jackson, 2009). Dessler (2014) defined human resource management as the process of obtaining, training, assessing, and providing compensation to employees, paying attention to their work relationships, health, safety, and the justice issues.

According to Robbins and Judge (2015), a leader is required to have technical skills, the type of skills in applying knowledge and expertise possessed and human skills, the ability to cooperate, understand and motivate others, both individuals and groups. Whereas conceptual skills are related to the mental ability to analyze and diagnose complex situations, for example, making a decision. Transformational leadership is defined by Bass and Avolio (2003) as the leader's ability to change the work environment, work patterns, and work values perceived by subordinates so that they are more capable of optimizing performance to achieve organizational goals.

Generally, work environment consists of two types of environment: non-physical work environment and physical work environment (Siagian, 2008). Robbins (2010) explained that the physical work environment is also a factor causing employee work stress that affects work performance. Factors affecting the physical work environment are: (a) temperature, (b) noise, (c) lighting, and (d) air quality. Mangkunegara (2013) stated that non-physical work environment is all conditions related to work relationships, both with superiors and colleagues or relations with subordinates. This non-physical work environment is something that cannot be ignored.

According to Simamora (2004), compensation includes financial rewards, tangible services, and benefits received by employees as part of employment relations. Bassed on Dessler (2014), compensation is divided into two parts: (1) Direct financial payments (wages, salaries, incentives, commissions, and bonuses) and (2) Indirect financial payments (entertainment insurance paid by the employer).

Robbins (as quoted in Cepi Triatna, 2015) proposed that job satisfaction is a general attitude towards someone's job showing the difference between the number of awards received and the amount they believe they should receive. Rivai (2006) proposed several factors that influence job satisfaction: 1) financial compensation, 2) leadership, 3) education and training, 4) work environment, 5) employee status.

The research study is focused on teacher satisfaction of SMKN 2 Kendari. This conceptual framework for research is based on thinking of changes in the Human Resources Management (HRM) paradigm and organizational behavior in an institution that has experienced a shift as the basis for the design of the conceptual framework. Teacher satisfaction referred to in this study is closely related to the attitudes of employees towards their work, work situations, cooperation between leaders and employees both from financial aspects, physical aspects, social aspects, and psychological aspects. Therefore, the measurement of teacher job satisfaction uses five indicators that refer to As'ad's (2004) opinion: (1) financial, (2) physical, (3) social, and (4) psychological. Actually, the research's conceptual framework is built based on theoretical and empirical studies as a basis for formulating problems, objectives, and hypotheses. The conceptual framework of this study 
begins with a theoretical study that examines relevant theories: HRM and Organizational Behavior theory are furthermore followed by transformational leadership style theories, work environment theories, compensation theories, and job satisfaction theories. The conceptual framework for this study is clearer shown in Figure 1 below:

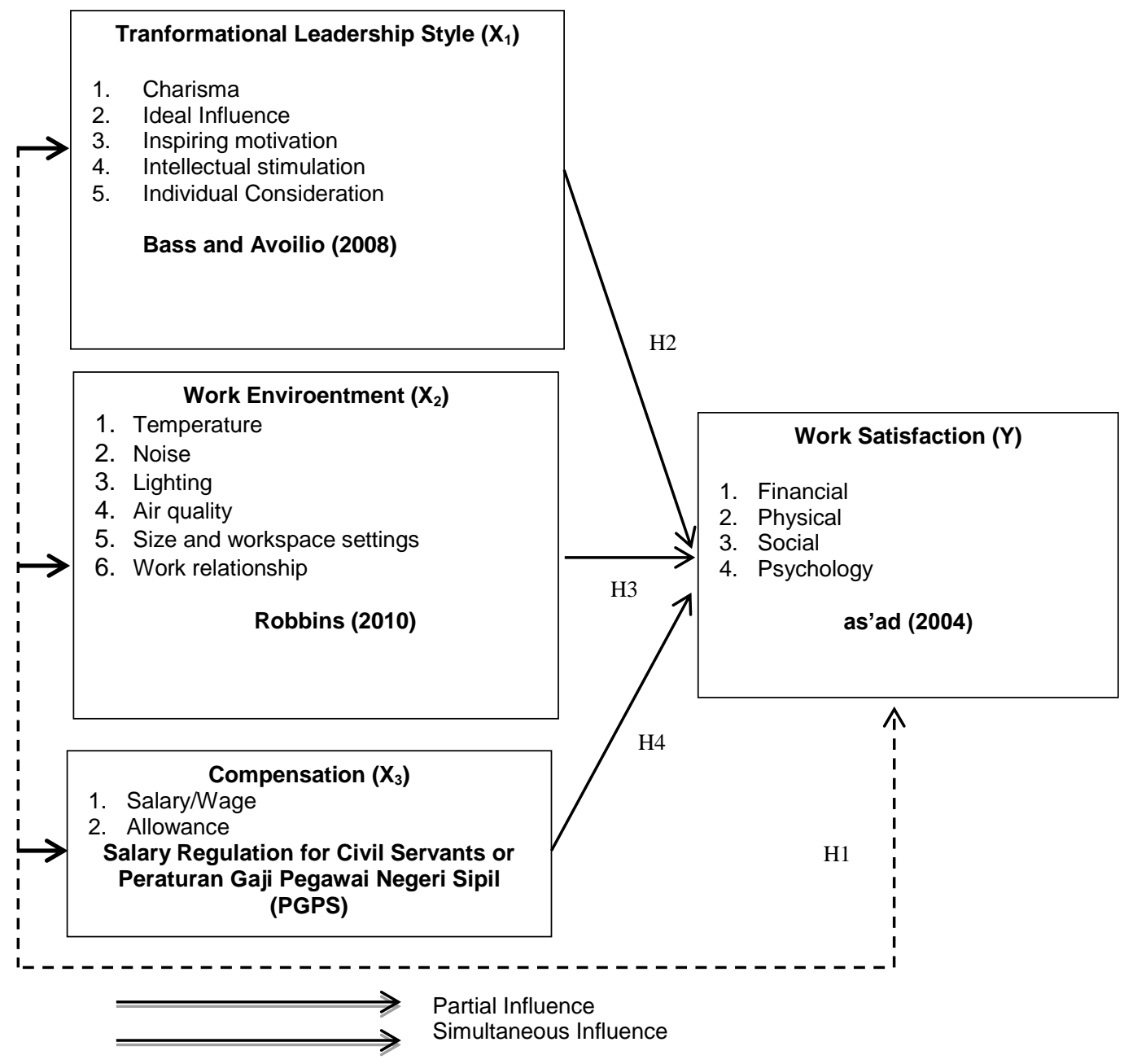

Figure 1 - Conceptual Framework

Based on the research framework, the hypotheses are as follows:

- Hypothesis 1: Transformational leadership style, work environment, and compensation had a positive and significant effect on teacher satisfaction of SMKN 2 Kendari;

- Hypothesis 2: Transformational leadership style had a positive and significant effect on teacher satisfaction of SMKN 2 Kendari;

- Hypothesis 3: Work environment had a positive and significant effect on teacher satisfaction of SMKN 2 Kendari;

- Hypothesis 4: Compensation had a positive and significant effect on teacher satisfaction of SMKN 2 Kendari.

\section{METHODS OF RESEARCH}

The objectives of this study were to address the problems described in the previous chapter and test the hypothesis of the influence of transformational leadership, work environment, and compensation on teacher satisfaction of SMKN 2 Kendari. According to Sugiyono (2013), associative explanatory research is aimed at finding out the relationship 
between two or more variables by examining causal relationships between variables. The sample is part or representative of the population of 112 respondents studied (Arikunto, 2006). The sampling technique is the respondent who will be used as that refers to a predetermined population. According to Bungin (2010), Slovin formula can be used to determine the number of samples. From the calculation above, the samples obtained were 53 respondents. The sampling method used was a simple random sampling. In this case, all populations have the same opportunity to be selected as a sample.

\section{RESULTS OF STUDY}

The Results of Hypothesis Testing. Tests to measure the ability of the independent variables in explaining the variables used the coefficient of determination $\left(R^{2}\right)$, while the simultaneous test of the variable $(X)$ against the dependent variable $(Y)$ used the $F$ test. On the other hands, $t$-test was used to test the partial effect of the independent variable $(X)$ on the dependent variable $(Y)$. The results of F-test and t-test can be seen in the table below:

Table 1 - F-Test Result

ANOVAa

\begin{tabular}{|c|c|c|c|c|c|}
\hline Model & Sum of Squares & Df & Mean Square & $F$ & Sig. \\
\hline 1 Regression & 1131.718 & 3 & 377.239 & 258.700 & $0.000^{b}$ \\
\hline Residual & 71.452 & 49 & 1.458 & & \\
\hline Total & 1203.170 & 52 & & & \\
\hline
\end{tabular}

Dependent Variable: Work Satisfaction. Predictors: (Constant), Compensation, Transformational, Work Environment. Source: Primary Data (processed), 2019.

Table 2 - t-test results

Coefficients ${ }^{a}$

\begin{tabular}{|c|c|c|c|c|c|}
\hline \multirow{2}{*}{ Model } & \multicolumn{2}{|c|}{ Unstandardized Coefficients } & \multirow{2}{*}{$\frac{\text { Standardized Coefficients }}{\text { Beta }}$} & \multirow{2}{*}{$\mathrm{t}$} & \multirow{2}{*}{ Sig. } \\
\hline & $B$ & StdError & & & \\
\hline 1 (Constan) & 1.373 & 1.700 & & 0.808 & 0.423 \\
\hline Tranformational Leadership & 0.459 & 0.060 & 0.457 & 7.643 & 0.000 \\
\hline Work Environment & 0.178 & 0.037 & 0.199 & 4. 825 & 0.000 \\
\hline Compensation & 0.817 & 0.102 & 0.447 & 8. 024 & 0.000 \\
\hline
\end{tabular}

Dependent Variable: Work Satisfaction.

\section{DISCUSSION OF RESULTS}

The Influence of Transformational Leadership Style, Work Environment, and Compensation on Teacher Satisfaction of SMKN 2 Kendari. Transformational Leadership Style, work environment, and compensation simultaneously having a positive and significant effect on Teacher Satisfaction of SMKN 2 can be accepted/proven. The results showed that F-count $>$ F-table $(258.700>2.79)$ with a significant value 0.000 , meaning smaller than $a=$ 0.05 (0. $000<0.05)$. Hence, the regression model can be used to predict Teacher Satisfaction by considering transformational leadership style (X1), work environment (X2), and compensation (X3) simultaneously or jointly having a positive and significant effect on teacher satisfaction of SMKN 2 Kendari $(Y)$. This research results proved that the truth of the Transformational Leadership Style theory is the synthesis result of Path-Goal Leadership Theory. The results of this study also reinforced Zulkarnaen's (2018) research entitled "The Effect of Transformational Leadership Style and Compensation on Employee Satisfaction. " The results revealed that transformational leadership and compensation had a positive and significant effect on employee satisfaction. Another study was conducted by Rhatih Enda Pramesty (2014), entitled "The influence of leadership style, compensation, and work environment on employee satisfaction. "The results showed the leadership style, compensation, and work environment had a positive and significant effect on employee satisfaction. 
The Influence of Transformational Leadership Style on Teacher Satisfaction of SMKN 2 Kendari. Transformational Leadership Style having a positive and significant effect on Teacher Satisfaction of SMKN 2 Kendari can be accepted/proven. The test results proved that Transformational Leadership Style (X1) had t-count $>$ t-table $(7.643>2$. 00958) with $t$ significance 0.000 , meaning smaller than $a=0.05(0.000<0.05)$ so the hypothesis is accepted. It can be said that the transformational leadership style partially had a positive and significant effect on teacher satisfaction of SMKN 2 Kendari (Y). This results reinforce the empirical research conducted by Choi Sang Long et al. (2014), Yenny Anggraeni (2013), Ida Prastiowati (2015), Zulkarnaen (2018), Muhammad Ikram Idrus (2016), and Putu Sudiarta (2018) who proved that transformational leadership style had a positive and significant influence on job satisfaction. However, there are differences or contradictions in research results (2018) research results, which found that transformational leadership style had no significant effect on job satisfaction. The fundamental difference from this research results and previous ones is the characteristics of the objects. Previous studies were mostly conducted in a company while this research was done at the school where the independence in carrying out the task is still intervented by other parties. Also, the sample characteristics and analysis methods were different.

The Influence of Work Environment on Teacher Satisfaction of SMKN 2 Kendari. Work Environment having a positive and significant effect on teacher satisfaction of SMKN 2 Kendari can be accepted/proven. The test results proved that the work environment (X2) had $\mathrm{t}$-count $>$ t-table $(4.825>2.00958)$ with t-value 0.000 , meaning smaller than $a=0.05(0$. $000<0.05)$ so the hypothesis is accepted. It can be said that the work environment partially had a positive and significant effect on teacher satisfaction of SMKN 2 Kendari ( $\mathrm{Y}$ ). The results of this study reinforce Sedarmayanti's (2009) opinion stating that work environment is a tool and material faced, work environment, working methods, and work arrangements both as individuals and as groups. This research results reinforce the empirical study conducted by George Kafui Agbozo (2017), Nancy L. Pioh and Hendra N. Tawas (2016), Abdurrahman Yusuf (2017), Rhatih Enda Pramesty (2014), Himawan Chandra Hadinata (2014), and PutuSudiarta (2018) which proved that the work environment had a positive and significant influence on employee satisfaction. However, there are differences or contradictions in Bagus Dhermawan (2012) and Musriha's (2013) result that the work environment had no significant effect on employee satisfaction. The fundamental difference from this research results and previous ones is the characteristics of the objects. Previous studies were mostly conducted in a company while this research was done at the school where the independence in carrying out the task is still intervented by other parties. Also, the sample characteristics and analysis methods were different.

The Influence of Compensation on Teacher Satisfaction of SMKN 2 Kendari. Compensation having a positive and significant effect on the Teacher satisfaction of SMKN 2 Kendari can be accepted/proven. The test results proved that the Compensation (X2) had tcount $>$ t-table $(8.024>2$. 00958) with t-value 0. 000, meaning smaller than $a=0.05(0.000$ $<0$. 05) so the hypothesis is accepted. It can be said that the compensation partially had a positive and significant effect on teacher satisfaction of SMKN 2 Kendari (Y). The results of this study also strengthen Handoko's (2000) opinion that compensation can increase employee satisfaction. The results of this study reinforce the empirical study conducted by Josephine Peprah-Mensah et al. (2017), Akhwanul Akmal \& Ihda Tamini (2015), Anak Agung Ngurah Bagus Dhermawan et al. (2012), I Gede Mahendrawan and Ayu Desi Indrawati (2015), Sinollah (2011) which proved that compensation had a positive and significant effect on employee satisfaction. However, there are differences or contradictions in Nancy L. Pioh and Hendra N. Tawas (2016), which proved that compensation had no significant influence on job satisfaction.

\section{CONCLUSION}

Transformational Leadership Style, Work Environment, and Compensation simultaneously have a positive and significant effect on Teacher Satisfaction of SMKN 2 
Kendari. This means that well-applied transformational leadership styles, hralth work environment, and good compensation will improve and increase teacher satisfaction.

Transformational Leadership Style partially has a positive and significant effect on teacher satisfaction of SMKN 2 Kendari.

Work environment partially has a positive and significant effect on teacher satisfaction of SMKN 2 Kendari.

Compensation partially has a positive and significant effect on teacher satisfaction of SMKN 2 Kendari.

\section{SUGGESTIONS}

The Principal of SMK Negeri 2 Kendari should continuously maintain his transformational leadership because it will provide satisfaction for teachers to perform their job. Conversely, if the leadership is not as expected, teacher satisfaction is declining. Leadership really determines the success of a teacher in teaching in class. The work environment also affects teacher satisfaction, the more supportive the work environment, the better the teacher's performance. Besides the principal's leadership and work environment, compensation also affects teacher satisfaction. The determination of the amount of compensation must follow the level of difficulty of the work charged to each teacher because the balance between the burden and the compensation will increase teacher satisfaction in performing his/her work.

Future researchers are expected to be able to utilize and develop the results of this study by using different variables and indicators, increasing the number of samples, and expanding the scope of research.

\section{REFERENCES}

1. Sihotang. 2007. "Manajemen Sumber Daya Manusia". Prandya Paramita. Jakarta.

2. Abdul Malik Karim Amrullah and Hengky Pramusinto. 2017. "Pengaruh Kepemimpinan Kepala Desa, Fasilitas Kantor, and Kompensasi Terhadap Kinerja se-Kecamatan Sukerejo". Economic Education Anlysis Journal, EEAJ 4(1), pp. 912-922.

3. Adya Hermawati and Nasharuddin Mas. 2017. "Mediation Effect of Quality of Worklife, Job Involvement and Organizational Citizenship Behavior in Relationship Between Transglobal Leadership to Employee Performance". International Journal of Law and Management. https://doi. org/10.1108/IJLMA-08-2016-0070 (Akses Tanggal 19 November 2018).

4. Ahyari, Agus. 2005. "Manajemen Produksi Perencanaan Sistem Produksi". Buku 2. Yogyakarta: BPFE.

5. Alex, S. Nitisemito. 1983. "Manajemen Personalisa: Manajemen Sumber Daya Manusia". Ghalia Indonesia. Jakarta.

6. Ambar, Teguh Sulistiyani, and Rosidah. 2003. "Manajemen Sumber Daya Manusia". Graha Ilmu. Yogyakarta

7. As'ad, Mohammad. 1998. "Psikologi Industri". Jakarta.

8. As'ad, Moh. 1965. "Sumber Daya Manusia Psikologi Industri”. Liberti. Yogyakarta.

9. Bass, B. M. , Avolio, B. J. , Jung, D. I. , and Berson, Y. 2003. "Predicting Performance by Assessing Transformational and Transactional Leadership". Journal of Applied Psychology, 88(2), pp. 207.

10. Bass, B. M. , Avolio, B. J. , Jung, D. I. , and Berson, Y. 2008. "Predicting Unit Performance by Assessing Transformational and Transactional Leadership". Journal of Applied Psychologi, 88(2), pp. 207.

11. Bass, B. M. , and Bass R. 2008. "The Bass Handbook of Leadership: Theory, Research and Managerial Applications (4thed. )". Free Press. New York.

12. Burn, James McGregor. 2010. "Leadership". HarperCollins. New York.

13. Cepi, Triatna. 2015. "Perilaku Organisasi”. PT Remaja Rosdakarya. Bandung. 
14. Chandra, Himawan Hadinata. 2014. "Pengaruh Lingkungan Kerja and Kompensasi terhadap Kepuasan Kerja Karyawan Pabrik Genteng Massoka Kebumen, Jawa Tengah. http://eprints. uny.ac.id/id/eprint/16787 (Akses Tanggal 20 November 2018).

15. Cooper, D. R. , and Schindler, P. S. , 2006. "Business Research Methods". Nine Edition. McGraw-Hill/lrwin. New York, NY 10020.

16. Dessler, Gary. 2014. "Manajemen Sumber Daya Manusia”. Selemba Empat. Jakarta.

17. Enda, Rhatih Pramesty. 2014. "pengaruh gaya kepemimpinan, kompensasi and lingkungan kerja terhadap kepuasan kerja karyawan (Studi kasus pada PT Personel Alih Daya Kta Jambi). http://eprints.ums.ac.id/id/eprint/31910 (Akses Tanggal 20 November 2018).

18. Flippo B, Edwin. 1993. "Manajemen Personalia". Erlangga. Jakarta.

19. Ghozali, Imam. 2016. "Aplikasi Analisis Multivariete Dengan Program IBM SPSS 23 (Edisi 8)". Cetakan ke VIII. Badan Penerbit Universitas Diponegoro. Semarang.

20. Handoko, T. Hani. 1984. "Manajemen". BPFE: Yogyakarta.

21. Handoko, T. Hani. 1985. "Manajemen Personalia and Sumber Daya Manusia". Yogyakarta: Liberty.

22. Handoko, T. Hani. 2000. "Manajemen Sumber Daya Manusia”. Yogyakarta: BPFE.

23. Haristryanto, Firman. 2012. "Pengaruh Kompensasi Terhadap Prestasi Kerja Karyawan". Fakultas Ekonomi and Bisnis Universitas Hasanuddin.

24. Harris, Michael. 2000. "Human Resource Management". 2th Edition. The Dryden Press. USA.

25. Hatane Semuel, Hotlan Siagian and Stefanie Octavia. 2017. "The Effect of Leadership and Innovation on Differentiation Strategy and Company Performance". Procedia-Social and Behavior Sciences 237, pp. 1152-1159.

26. Ivancevich, John M. , Robert Konopaske, Michael T. Matteson. 2014. "Organizational Behavior and Management". Thent Edition. Mc Graw Hill. USA.

27. Keith Davis and John W. Newstrom. 1994. "Perilaku Dalam Organisasi". PT. Gelora Aksara Pratama. Jakarta.

28. Kreitner, K. and A. Kinicki. 2014. "Organizational Behavior". Ten Edition. Mc Graw-Hill. New York.

29. Malthis and Jackson. 2009. "Manajemen Sumber Daya Manusia". Edisi 10. Selemba Empat. Jakarta.

30. Mangkunegara, A. P. 2013. "Manajemen Sumber Daya Perusahaan". Remaja Rosyakarya. Bandung.

31. Martoyo, Susilo. 2000. "Manajemen Sumber Daya Manusia". Edisi Empat. Yogyakarta: BPFE.

32. Marwansyah. 2010. "Manajemen Sumber Daya Manusia”. Alfabeta. Bandung.

33. Masri Singarimbun and Sofyan Effendi. 1995. "Metode Penelitian Survei". Edisi Revisi. PT. Pustaka LP3ES. Jakarta.

34. Mengkuprawira, Sjafri. 2003. "Manajemen Sumber Daya Manusia Strategik”. Cetakan ke2, Ghalia. Indonesia.

35. Minto Waluyo. 2015. "Manajemen Psikologi Industri". PT. Indeks. Jakarta.

36. Moh. Nazir. 2003. "Metode Penelitian". Ghalia Indonesia. Jakarta.

37. Mondy, Wayne. 2008. "Manajemen Sumber Daya Manusia". PT. Gelora Aksara Pratama. Jakarta.

38. Nitisemito Alex S. , 2004. "Manajemen Personalia". Ghalia Indonesia. Jakarta.

39. Panggabean, M. 2007. "Manajemen Sumber Daya Manusia". Ghalia. Bogor.

40. Peraturan Pemerintah (PP) Nomor 7 Tahun 1977 tentang Peraturan Gaji Pegawai Negeri Sipil (PGPS).

41. Rivai, Veithzal. 2006. "Manajemen Sumber Daya Manusia Untuk Perusahaan, Dari Teori ke Praktik". PT. Raja Grafindo Persada. Jakarta.

42. Robbins, Stephent P. 1996. "Perilaku Organisasi". Edisi Bahasa Indonesia. Jakarta: Prenhallindo.

43. Robbins, S. P. , 2010. "Essential of Organizational Behavior". Edisi ke-16, Salemba Empat. Jakarta. 
44. Robbins, Stephen P. , Timothy A. Judge. 2015. "Organizational Behavior". 16 Edition. Pearson. England.

45. Robert L. Kazt. 2004. "Human Resource Management (Manajemen Sumber Daya Manusia)". Edisi Sepuluh, Terjemahan: Diana Angelica. Salemba Empat. Jakarta

46. Saragih, J, S. 2007. "Pengaruh Kepemimpinan Transformasional and Transaksional Terhadap Komunikasi and Kepuasan Kerja Studi pada Guru SMAK BPK Penabur Jakarta". Jurnal Pendidikan Penabur. No. 09/Tahun ke-6/Desember 2007. Jakarta.

47. Sedarmayanti. 2016. "Manajemen Sumber Daya Manusia Reformasi Birokrasi and Manajemen Pegawai Negri Sipil". Revika Aditama. Bandung.

48. Siagian S. 2008. "Manajemen Sumber Daya Manusia". Bumi Aksara. Jakarta.

49. Simamora, Hendry. 2004. "Manajemen Sumber Daya Manusia". STIE YKPN. Yogyakarta.

50. Siregar, Syofian. 2013. "Metode Penelitian Kuantitatif". PT. Fajar Interpratama Mandiri. Jakarta.

51. Sugiyono. 2009. "Metode Penelitian Kuantitatif, Kualitatif and R\&D”. Alfabeta. Bandung.

52. Sugiyono. 2013. "Penelitian Kuantitatif Kualitatif and R \& D". Alfabeta. Bandung.

53. Sugiyono, 2015. "Metode Penelitian and Pengembangan". Alfabeta. Bandung.

54. Utomo, Kabu Wahyu. 2002. "Kepemimpinan and Pengaruh Terhadap Perilaku Cityzenship (OCB), Kepuasan Kerja and Perilaku Organisasional (Penelitian Empiris pada PEMDA Kota Kebumen)". Jurnal Riset Ekonomi and Manajemen. Vol 2. Hal 34-52.

55. Veithzal, Rivai. 2008. "Manajemen Sumber Daya Manusia Untuk Perusahaan". PT. Raja Grafino Persada. Jakarta.

56. Veithzal Rivai, and Sagala, Eva J. 2014. "Manajemen Sumber Daya Manusia Untuk Perusahaan. PT. Raja Grafindo. Jakarta

57. Wirawan. 2013. "Kepemimpinan”. PT Raja Grafindo Persada. Jakarta. 